\title{
PENGGUNAAN MODEL PEMBELAJARAN KOOPERATIF TIPE STUDENT TEAMS ACHIEVEMENT DIVISION (STAD) DALAM MENINGKATKAN HASIL BELAJAR SISWA MATA PELAJARAN PENDIDIKAN AGAMA ISLAM
}

\author{
Fathus Saadah \\ SD Negeri 25 Lubuklinggau \\ fathussaadah2018@gmail.com
}

\begin{abstract}
ABSTRAK
Penelitian ini bertujuan untuk mengetahui peningkatan hasil belajar siswa pada pembelajaran Pendidikan Agama Islam kelas VI dengan menggunakan model Pembelajaran kooperatif Tipe Student Teams Achievement Division (STAD) pada materi di SD Negeri 42 Lubuklingga tahun pelajaran 2014/2015. Jenis penelitian ini termasuk penelitian action research. Subyek penelitian ini adalah siswa kelas VI SD Negeri 25 Lubuklinggau tahun pelajaran 2014/2015. Hasil penelitian ini menunjukkan: melalui hasil penelitian tindakan kelas pada SD Negeri 25 Lubuklinggau terjadi peningkatan. Pada siklus I, tingkat ketuntasan hanya sebesar 58,54\%. Pada siklus II tingkat ketuntasan meningkat menjadi 87,80\%. Berarti terdapat peningkatan hasil belajar siswa dan aktifitas proses pembelajaran para peserta didik setelah dilakukan penelitian tindakan kelas. Dengan demikian, dapat disimpulkan terdapat peningkatan hasil belajar yang signifikan sebelum dan sesudah diberikan tindakan kelas dengan menggunakan model Pembelajaran kooperatif Tipe Student Teams Achievement Division (STAD) pada siswa kelas VI SD Negeri 25 Lubuklinggau dalam aktifitas hasil belajar siswa. Maka penelitian ini dianggap berhasil dengan baik.
\end{abstract}

Kata Kunci: Model Pembelajaran Kooperatif, Hasil Belajar Siswa

\begin{abstract}
This study aims to determine the improvement of student learning outcomes in learning Islamic Religious Education class VI using cooperative learning model Type Student Teams Achievement Division (STAD) on the material in SD Negeri 42 Lubuklingga academic year 2014/2015. This type of research includes action research research. The subject of this research is the students of class VI SD Negeri 25 Lubuklinggau academic year 2014/2015. The results of this study indicate: through the results of classroom action research on SD Negeri 25 Lubuklinggau an increase. In the first cycle, the level of mastery only amounted to 58.54\%. In cycle II the level of mastery increased to $87.80 \%$. Means there is an increase in student learning outcomes and learning activities of the learners after classroom action research. Thus, it can be concluded that there is a significant improvement in
\end{abstract}


learning outcomes before and after classroom action using cooperative learning model Type Student Teams Achievement Division (STAD) in grade 6 students of SD Negeri 25 Lubuklinggau in student learning outcomes. So this research is considered to work well.

Keywords: Cooperative Learning Model, Student Learning Outcomes

\section{PENDAHULUAN}

Salah satu diantara masalah besar dalam bidang pendidikan di Indonesia yang banyak diperbincangkan adalah rendahnya mutu pendidikan yang tercermin dari rendahnya rata-rata hasil belajar. Masalah lain dalam pendidikan di Indonesia yang juga banyak diperbincangkan adalah bahwa pendekatan dalam pembelajaran masih terlalu didominasi peran guru (teacher center). Guru banyak menempatkan siswa sebagai obyek dan bukan sebagai subyek didik. Pendidikan kita kurang memberikan kesempatan pada siswa dalam berbagai mata pelajaran untuk mengembangkan kemampuan berpikir holistik (menyeluruh), kreatif, objektif, dan logis. Pendidikan merupakan suatu kegiatan yang universal dalam kehidupan manusia, karena dimanapun dan kapanpun dunia memerlukan pendidikan. Oleh karena itu, pembangunan di Indonesia mengarah pada upaya peningkatan harkat dan martabat serta kualitas sumber daya manusia Indonesia dengan memperluas dan meningkatkan pemerataan kesempatan dalam memperoleh pendidikan.

Sekolah adalah tempat bagi setiap peserta didik untuk belajar dan menuntut ilmu pengetahuan. Sekolah harus mampu berfungsi secar optimal sebagai tempat terjadinya proses belajar-mengajar antara guru dan peserta didik, dengan demikian sekolah dapat mewujudkan tujuan dari pendidikan nasional yang berfungsi mencerdaskan kehidupan bangsa dan memajukan kebudayaan nasional.Belajar merupakan sebuah proses yang kompleks yang terjadi pada semua orang dan berlangsung seumur hidup. Sedangkan pembelajaran adalah seperangkat tindakan yang dirancang untuk mendukung proses belajar siswa, dengan memperhitungkan kejadian-kejadian ekstrem yang berperan terhadap rangkaian kejadian-kejadian intern yang berlangsung dialami siswa. Sedangkan pembelajaran adalah seperangkat tindakan yang dirancang untuk mendukung proses belajar siswa, dengan memperhitungkan kejadian-kejadian ekstrem yang berperan terhadap rangkaian kejadian-kejadian intern yang berlangsung dialami siswa. (Winkel dalam Siregar dan Hartini Nara, 2010).

Peserta didik merupakan suatu komponen masukan dalam sistem pendidikan, yang selanjutnya diproses dalam proses pendidikan, sehingga menjadi manusia yang berkualitas sesuai dengan tujuan pendidikan nasional. Perkembangan peserta didik seutuhnya menggambarkan adanya suatu perubahan dalam diri seseorang, baik itu perkembangan fisik, emosional, sosial, intelegensi maupun perkembangan spiritual 
yang saling berhubungan satu dengan yang lainnya. Pendidikan di sekolah lebih dikenal dengan belajar mengajar. Proses belajar mengajar ini terjadi dengan melibatkan banyak faktor, baik pendidik, peserta didik, bahan atau materi, fasilitas maupun lingkungan. Namun corak dan bentuk pendidikan di sekolah semuanya berpusat pada aktivitas belajar siswa. Belajar harus direncanakan, disusun dan dievaluasi hasilnya.

Masalah utama dalam pembelajaran pada pendidikan formal adalah masih rendahnya daya serap peserta didik. Hal ini tampak dari rata-rata hasil belajar peserta didik yang belum mendapatkan nilai yang optimal. Hal ini merupakan hasil dari kondisi pembelajaran yang masih bersifat konvensional dan tidak menyentuh ranah dimensi peserta didik itu sendiri, selain itu proses pembelajaran masih didominasi oleh guru dan tidak memberikan akses bagi anak didik untuk berkembang secara mandiri dengan cara memanfaatkan berbagai sumber informasi dan linkungan sebagai sumber belajar. Dipihak lain secara empiris, berdasarkan hasil analisa penelitian terhadap rendahnya hasil belajar peserta didik yang disebabkan dominannya proses pembelajaran konvensioanl. pada pembelajaran ini suasana kelas cenderung teachercentered sehingga siswa menjadi pasif. Dalam hal ini siswa tidak diajarkan dapat memahami bagaimana belajar, berfikir dan memotivasi diri sendiri, padahal aspekaspek tersebut merupakan kunci keberhasilan dalam suatu pembelajaran. Masalah ini banyak dijumpai dalam kegiatan proses belajar mengajar di kelas, oleh karena itu perlu menerapkan model pembelajaran sehingga dapat membantu siswa untuk memahami materi ajar dan aplikasi serta relevansinya dalam kehidupan sehari-hari. (Trianto, 2011).

Menurut Soekamto,dkk (dalam Trianto, 2011) model pembelajaran merupakan kerangka konseptual yang melukiskan prosedur yang sitematis dalam mengorganisasikan pengalaman belajar untuk mencapai tujuan belajar tertentu, dan berfungsi sebagai pedoman bagi para perancang pembelajaran dan para pengajar dalam merencanakan aktivitas mengajar. Sedangkan pendekatan merupakan konsep dasar yang mewadahi dan melatari metode pembelajaran dengan cakupan teoritis tertentu.

Menurut Artzt dan Newman (dalam Trianto, 2011) menyatakan bahwa dalam belajar kooperatif siswa belajar bersama sebagai suatu tim dalam menyelesaikan tugas-tugas kelompok untuk mencapai tujuan bersama. Jadi, setiap anggota memiliki tanggung jawab yang sama untuk keberhasilan kelompoknya. Pemilihan model pembelajaran harus memiliki pertimbangan-pertimbangan misalnya, materi pelajaran, tingkat perkembangan kognitif peserta didik, dan sarana atau fasilitas yang tersedia, sehingga tujuan pembelajaran yang telah ditetapkan dapat tercapai (Trianto, 2011). Kenyataan di lapangan dalam proses pembelajaran siswa hanya menghafal konsep dan kurang mampu menggunkan konsep tersebut jika menemui masalah dalam 
kehidupan nyata yang berhubungan dengan konsep yang dimiliki. Lebih jauh lagi bahkan siswa kurang mampu menentukan masalah dan merumuskannya. Berbicara mengenai proses pembelajaran dan pengajaran yang tidak tepat terkadang membuat pemahaman siswa terhadap materi ajar kurang dapat diterima siswa. Walaupun demikian, kita menyadari bahwa ada siswa yang mampu menghafal materi yang diterimanya, namun kenyataanya mereka sering kurang memahami dan mengerti secara mendalam pengetahuan yang bersifat hafalan tersebut. Sehingga siswa kurang mampu menghubungkan antara apa yang mereka pelajari dengan bagaimana pengetahuan tersebut akan dimanfaatkan atau diaplikasikan (Trianto,2011).

Berdasarkan alasan tersebut, maka sangatlah penting bagi para pendidik sebagai seorang guru untuk memahami karakteristik materi, karakteristik peserta didik, dan metodelogi pembelajaran dalam proses pembelajaran terutama berkaitan pemilihan terhadap model pembelajaran dan pendekatan dalam proses pembelajaran. Dengan demikian, proses pembelajaran yang diselenggarakan akan lebih efektif dan produktif. Materi pelajaran akan tambah berarti jika peserta didik mempelajari materi pelajaran yang disajikan dengan proses pembelajaran yang dapat menambah motivasi belajar bagi peserta didik, dan dapat memenfaatkan berbagai sumber informasi sebagai sumber belajar, sehingga pembelajaran akan menjadi lebih berarti dan menyenangkan. Peserta didik akan lebih semangat untuk mencapai tujuan pembelajaran, mereka menggunakan pengalaman dan pengetahuan sebelumnya untuk membangun pengetahuan baru. Dan, selanjutnya siswa memanfaatkan kembali pemahaman pengetahuan dan kemampuannya itu di dalam berbagai konteks diluar sekolah untuk menyelesaikan masalah dunia nyata yang kompleks, baik secara mandiri maupun dengan berbagai kombinasi dan struktur kelompok. (Trianto,2011).

Model pembelajaran yang dapat digunakan guru hendaknya dapat menghasilkan hasil belajar siswa yang lebih baik diantaranya adalah model pembelajaran kooperatif tipe Student Team Achievement Division (STAD), dalam pembelajaran Pendidikan Agama Islam (PAI). Student team achievement division termasuk dalam model pembelajaran kooperatif yang dapat meningkatkan rasa percaya diri dan keaktifan siswa dalam belajar hal ini dikarenakan setiap kelompok terdiri dari empat atau lima orang sehingga setiap siswa akan mendapatkan kesempatan untuk berpartisipasi dalam kelas.

Pendidikan Agama Islam (PAI) merupakan pelajaran yang harus diajarkan kepada peserta didik. Pelajaran Pendidikan Agama Islam (PAI) mempelajari benda konkret, peristiwa, maupun kejadian-yang terjadi dalam kehidupan sehari-hari yang berkaitan dengan agama akan tetapi penerapanya belum disadari oleh siswa padahal hal tersebut sering terjadi dan dialami. Pendidikan Agama Islam (PAI)merupakan salah satu bidang studi yang dianggap sulit, untuk menghilangkan anggapan tersebut pengajaran Pendidikan Agama Islam (PAI) sebaiknya disajikan secara 
menarik.Berdasarkan hasil pengamatan penulis di SD Negeri 25 Lubuklinggau bahwa hasil belajar Pendidikan Agama Islam (PAI) siswa SD Negeri 25 Lubuklinggau masih di bawah kriteria ketuntasan minimum (KKM) yang ditetapkan yaitu 65. Hal ini dikarenakan model pembelajaran yang digunakan di sekolah tersebut masih konvensional dan berpusat pada guru. Oleh karena itu model pembelajaran yang digunakan haruslah sesuai dan tepat agar dapat memotivasi siswa untuk belajar sehingga hasil belajar Pendidikan Agama Islam (PAI) siswa dapat meningkat.

\section{METODE PENELITIAN}

Penelitian ini merupakan penelitian tidakan (action research). Dalam kegiatan ini, guru terlibat langsung secara penuh dalam proses perencanaan tindakan, observasi dan refleksi kehadiran pihak lain dalam penelitian ini peranannya tidak didominan dan sangat kecil. Penelitian ini bertempat di SD Negeri 25 Lubuklinggau. Penelitian ini dilaksanakan pada bulan September sampai Oktober semester ganjil 2014/2015. Subyek penelitian adalah siswa-siswi kelas VI SD Negeri 25 Lubuklinggau dengan jumlah 41 siswa, pada pokok bahasan ibadah di bulan Ramadan. Data-data yang diperlukan dalam penelitian ini diperoleh melalui observasi pengolahan metode pembelajaran kooperatif model STAD, observasi aktivitas siswa dan guru, dan tes formatif.

Penelitian ini menggunakan model penelitian tindakan dari Kemmis dan Taggart (dalam Arikunto, 2002), yaitu berbentuk spiral dari siklus yang satu ke siklus yang berikutnya. Setiap siklus meliputi planning (rencana), action (tindakan), observasi (pengamatan) dan reflection (refleksi). Langkah pada siklus berikutnya adalah perencanaan yang sudah direvisi, tindakan, pengamatan dan refleksi. Sebelum masuk pada siklus I dilakukan tindakan pendahuluan yang berupa identifikasi permasalahan.

Untuk mengalisis tingkat keberhasilan atau persentase keberhasilan siswa setelah proses belajar mengajar setiap putarannya dilakukan dengan cara memberikan evaluasi berupa soal tes tertulis pada setiap akhir putaran. Analisis ini dihitung dengan menggunakan statistic sederhana yaitu:

1. Untuk menilai ulangan atau tes formatif. Menurut Slameto (2010) data tentang nilai hasil belajar (kognitif) siswa dihitung dengan menggunakan rumus sebagai berikut :

$$
\text { Nilai Akhir }=\frac{\text { Jumlah jawaban benar }}{\text { Jumlah seluruh soal }} \times 100
$$


Hasil penelitian dianalisis 3 kali yaitu analisis untuk menghitung rata-rata kelas, menentukan ketuntasan belajar secara individual dan menentukan ketuntasan belajar secara klasikal.

2. Menentukan rata-rata kelas. Menurut Sudjana (2005) untuk mengetahui nilai rata-rata kelas pada masing-masing siklus sebagai berikut:

$$
\bar{X}=\frac{\sum X}{N}
$$

Keterangan :

$$
\begin{aligned}
& \overline{\mathrm{X}} \quad \text { Nilai rata-rata (mean) } \\
& \sum X=\text { Jumlah nilai seluruh siswa } \\
& \mathrm{N} \quad=\text { Banyaknya siswa yang mengikuti test }
\end{aligned}
$$

3. Menentukan ketuntasan belajar secara individual. Analisis ini digunakan untuk mengetahui tingakat penguasaan tiap indikator dan kompetensi dasar dari tes yang diujikan. Rumus yang digunakan deskriptif prosentase yang menggambarkan besarnya tingkat penguasaan materi (Ali, 2013) yaitu:

$$
\mathrm{TP}=\frac{n}{\mathrm{~N}} \times 100 \%
$$

Keterangan:

TP: prosentase penguasaan materi

$\mathrm{n}$ : skor yang diperoleh responden

$\mathrm{N}$ : skor maksimal

Dalam penelitian ini digunakan standar penguasaan $70 \%$ artinya siswa yang tingkat penguasaan materinya kurang dari $70 \%$ dikatakan belum tuntas belajar.

4. Menentukan ketuntasan belajar secara klasikal. Rumus yang digunakan untuk mengetahui ketuntasan belajar siswa secara klasikal menurut Ali (2013) sebagai berikut:

$$
\begin{aligned}
& \mathrm{P}=\frac{\sum n 1}{\mathrm{n}} \times 100 \% \\
& \text { Keterangan: } \\
& \mathrm{P} \quad \text { : nilai ketuntasan belajar } \\
& \sum \mathrm{n} 1 \text { : jumlah siswa tuntas belajar secara klasikal } \\
& \mathrm{n} \quad \text { : jumlah total siswa }
\end{aligned}
$$


Indikator keberhasilan dalam penelitian ini adalah meningkatnya pemahaman belajar siswa yang ditunjukkan dengan meningkatnya hasil belajar siswa dibandingkan dengan tahun sebelumnya yaitu minimal siswa memperoleh nilai 65 . Hal tersebut didasarkan pada teori belajar tuntas, maka seorang peserta didik dipandang tuntas belajar jika ia mampu menyelesaikan, menguasai kompetensi atau mencapai tujuan pembelajaran minimal $65 \%$ dari seluruh tujuan pembelajaran (Mulyasa, 2004). Sedangkan untuk keberhasilan klasikal jika 85\% dari seluruh siswa memperoleh nilai $\geq 65$.

\section{HASIL PENELITIAN}

\section{Siklus I}

Tahap Perencanaan. Pada tahap ini peneliti mempersiapkan perangkat pembelajaran yang terdiri dari rencana pelajaran 1, LKS 1, soal tes formatif 1 dan alat-alat pengajaran yang mendukung. Tahap Kegiatan dan Pelaksanaan. Pelaksanaan kegiatan belajar mengajar untuk siklus I dilaksanakan pada tanggal 3 September 2014 di kelas VI SD Negeri 25 Lubuklinggau dengan jumlah 41 siswa. Dalam hal ini peneliti bertindak sebagai guru. Adapun proses belajar mengajar mengacu pada rencana pelajaran yang telah dipersiapkan. Pengamatan (observasi) dilaksanakan bersamaan dengan pelaksaaan belajar mengajar. Pada akhir proses belajar mengajar siswa diberi tes formatif I dengan tujuan untuk mengetahui tingkat keberhasilan siswa dalam proses belajar mengajar yang telah dilakukan. Adapun data hasil penelitian pada siklus I adalah sebagai berikut:

Tabel 1

Pengelolaan Pembelajaran Pada Siklus I

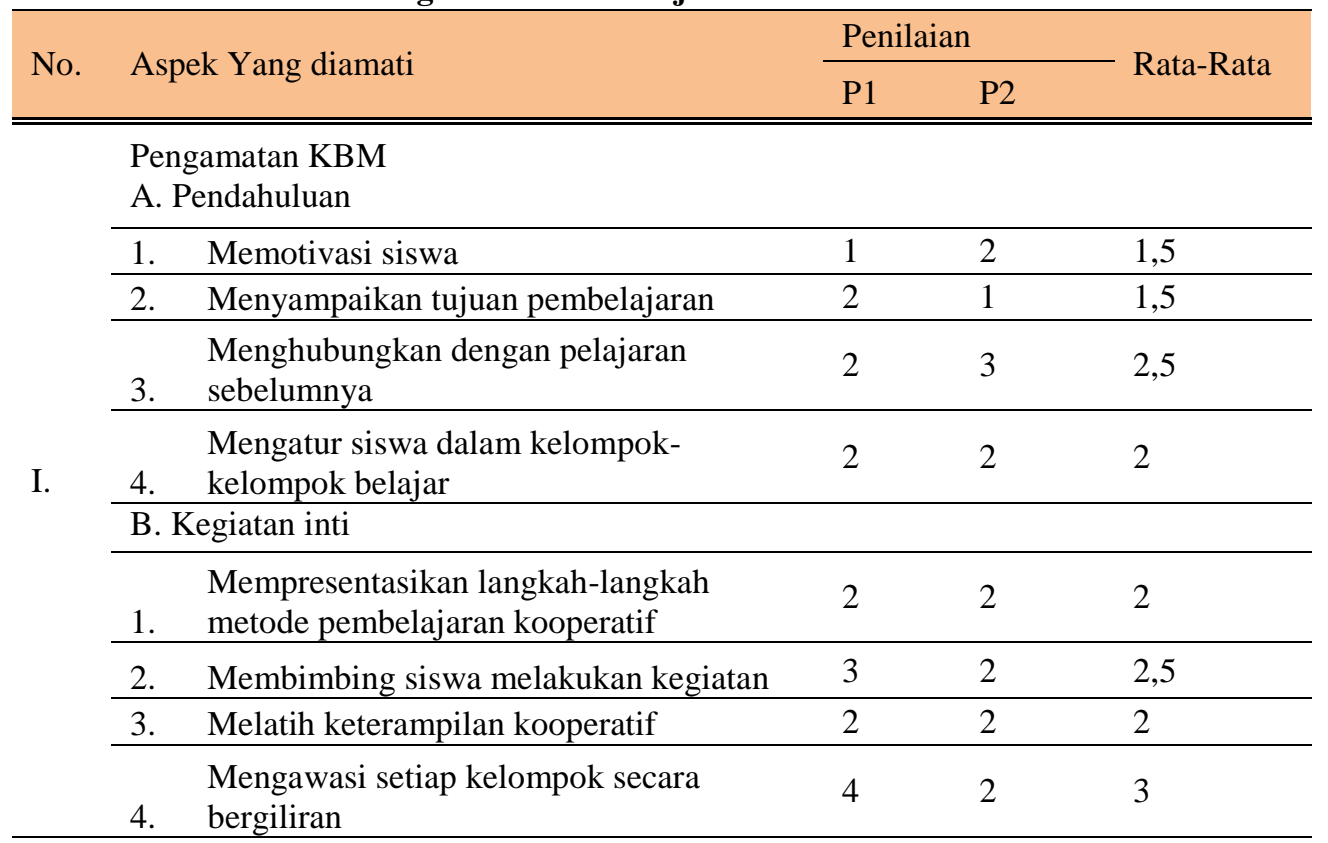


Memberikan bantuan kepada kelompok

$\begin{array}{llll}\text { yang mengalami kesulitan } & 1 & 3 & 2\end{array}$

\begin{tabular}{|c|c|c|c|c|}
\hline \multicolumn{5}{|c|}{ C. Penutup } \\
\hline & 1. Membimbing siswa membuat rangkuman & 2 & 3 & 2,5 \\
\hline & 2. Memberikan evaluasi & 2 & 1 & 1,5 \\
\hline \multirow[t]{2}{*}{ II. } & Pengelolaan Waktu & 2 & 1 & 1,5 \\
\hline & Antusiasme Kelas & & & \\
\hline \multirow[t]{2}{*}{ III. } & 1. Siswa antusias & 2 & 3 & 2,5 \\
\hline & 2. Guru antusias & 2 & 1 & 1,5 \\
\hline \multicolumn{2}{|c|}{ Jumlah } & 29 & 28 & 28,5 \\
\hline & \multirow[t]{5}{*}{ Keterangan: } & Nilai & \multicolumn{2}{|c|}{ Kriteria } \\
\hline & & 1 & \multicolumn{2}{|c|}{ Tidak Baik } \\
\hline & & 2 & \multicolumn{2}{|c|}{ Kurang Baik } \\
\hline & & 3 & \multicolumn{2}{|c|}{ Cukup Baik } \\
\hline & & 4 & \multicolumn{2}{|c|}{ Baik } \\
\hline
\end{tabular}

Berdasarkan tabel di atas aspek-aspek yang mendapatkan kriteria kurang baik adalah memotivasi siswa, menyampaikan tujuan pembelajaran, pengelolaan waktu, dan siswa antusias. Keempat aspek yang mendapat nilai kurang baik di atas, merupakan suatu kelemahan yang terjadi pada siklus I dan akan dijadikan bahan kajian untuk refleksi dan revisi yang akan dilakukan pada siklus II. Hasil observasi berikutnya adalah aktivitas guru dan siswa seperti pada tabel berikut :

Tabel 2

Aktivitas Guru Dan Siswa Pada Siklus I

\begin{tabular}{|c|c|c|c|}
\hline 0. & Aktivitas Guru yang diamati & $\mathrm{e}$ & Persentas \\
\hline & Menyampaikan tujuan & & 3,00 \\
\hline & Memotivasi siswa & & 3,00 \\
\hline & Mengkaitkan dengan pelajaran sebelumnya & & 2,50 \\
\hline & Menyampaikan materi/ langkah-langkah/ strategi & & 2,00 \\
\hline & Menjelaskan materi yang sulit & & 2,50 \\
\hline & \multicolumn{2}{|l|}{ 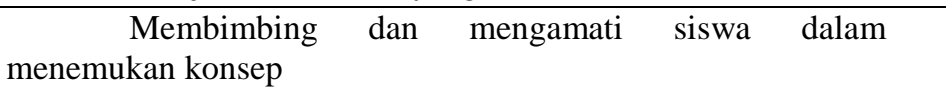 } & 2,50 \\
\hline & \multicolumn{2}{|l|}{$\begin{array}{l}\text { Meminta siswa menyajikan dan mendiskusikan hasil } \\
\text { kegiatan }\end{array}$} & 2,50 \\
\hline & Memberikan umpan balik & & 1,50 \\
\hline & Membimbing siswa merangkum pelajaran & & 1,49 \\
\hline 0. & Aktivitas siswa yang diamati & $\mathrm{e}$ & Persentas \\
\hline
\end{tabular}




\begin{tabular}{ll} 
Mendengarkan/ memperhatikan penjelasan guru & 16,00 \\
\hline Membaca buku & 16,00 \\
\hline Bekerja dengan sesama anggota kelompok & 16,00 \\
\hline Diskusi antar siswa/ antara siswa dengan guru & 16,00 \\
\hline Menyajikan hasil pembelajaran & 8,00 \\
\hline Menyajikan/ menanggapi pertanyaan/ ide & 16,00 \\
\hline Menulis yang relevan dengan KBM & 24,00 \\
\hline Merangkum pembelajaran & 16,00 \\
\hline Mengerjakan tes evaluasi & 21,50 \\
\hline
\end{tabular}

Berdasarkan tabel di atas tampak bahwa aktivitas guru yang paling dominan pada siklus I adalah membimbing dan mengamati siswa dalam menemukan konsep, yaitu $2,50 \%$. Aktivitas lain yang presentasinya cukup besar adalah menyampaikan tujuan, memotivasi siswa yaitu masing-masing sebesar 3,00\%. Sedangkan aktivitas siswa yang paling dominan adalah menulis yang relevan dengan KBM yaitu 24,00\%. Aktivitas lain yang presentasinya cukup besar adalah bekerja dengan sesama anggota kelompok, diskusi antara siswa/ antara siswa dengan guru, dan membaca buku yaitu masing-masing 16,00\%. Pada siklus I, secaraa garis besar kegiatan belajar mengajar dengan metode pembelajaran kooperatif model STAD sudah dilaksanakan dengan baik, walaupun peran guru masih cukup dominan untuk memberikan penjelasan dan arahan, karena model tersebut masih dirasakan baru oleh siswa.

Tabel 3.

Rekapitulasi Hasil Tes Formatif Pada Siklus I

\begin{tabular}{|c|c|c|}
\hline & Uraian & Hasil Siklus I \\
\hline . & Nilai rata-rata tes formatif & 65.10 \\
\hline • & Jumlah siswa yang tuntas belajar & 24 \\
\hline • & Persentase ketuntasan belajar & 58.54 \\
\hline
\end{tabular}

Dari tabel di atas dapat dijelaskan bahwa dengan menerapkan model pembelajaran kooperatif tipe STAD diperoleh nilai rata-rata hasil belajar siswa adalah 65.10 dan ketuntasan belajar mencapai $58.54 \%$ atau ada 24 siswa dari 41 siswa sudah tuntas belajar. Hasil tersebut menunjukkan bahwa pada siklus pertama secara klasikal siswa belum tuntas belajar, karena siswa yang memperoleh nilai $\geq 65$ hanya sebesar $58.54 \%$ lebih kecil dari persentase ketuntasan yang dikehendaki yaitu sebesar $85 \%$. Hal ini disebabkan karena siswa masih merasa baru dan belum mengerti apa yang dimaksudkan dan digunakan guru dengan menerapkan model pembelajaran kooperatif tipe STAD. 
Refleksi. Dalam pelaksanaan kegiatan belajar mengajar diperoleh informasi dari hasil pengamatan sebagai berikut: a) guru kurang baik dalam memotivasi siswa dan dalam menyampaikan tujuan pembelajaran, b) guru kurang baik dalam pengelolaan waktu, c) Siswa kurang begitu antusias selama pembelajaran berlangsung. Revisi. Pelaksanaan kegiatan belajar mengajar pada siklus I ini masih terdapat kekurangan, sehingga perlu adanya revisi untuk dilakukan pada siklus berikutnya.

\section{Siklus II}

Tahap perencanaan. Pada tahap ini peneliti mempersiapkan perangkat pembelajaran yang terdiri dari rencana pelajaran 2, LKS, 2, soal tes formatif II dan alat-alat pengajaran yang mendukung. Tahap kegiatan dan pelaksanaan. Pelaksanaan kegiatan belajar mengajar untuk siklus II dilaksanakan pada tanggal 10 September 2014 di kelas VI SD Negeri 25 Lubuklinggau dengan jumlah 41 siswa. Dalam hal ini peneliti bertindak sebagai guru. Adapun proses belajar mengajar mengacu pada rencana pelajaran dengan memperhatikan refisi pada siklus I, sehingga kesalahan atau kekurangan pada siklus I tidak terulanga lagi pada siklus II. Pengamatan (observasi) dilaksanakan bersamaan dengan pelaksanaan belajar mengajar. Pada akhir proses belajar mengajar siswa diberi tes formatif II dengan tujuan untuk mengetahui tingkat keberhasilan siswa dalam proses belajar mengajar yang telah dilakukan. Instrumen yang digunakan adalah tes formatif II. Adapun data hasil penelitian pada siklus II adalah sebagai berikut:

Tabel 4

Pengelolaan Pembelajaran Pada Siklus II

\begin{tabular}{|c|c|c|c|c|}
\hline \multirow{2}{*}{ No. } & \multirow{2}{*}{ Aspek Yang diamati } & \multicolumn{2}{|c|}{ Penilaian } & \multirow{2}{*}{ Rata-Rata } \\
\hline & & $\mathrm{P} 1$ & $\mathrm{P} 2$ & \\
\hline \multirow{10}{*}{ I. } & Pengamatan KBM & & & \\
\hline & A. Pendahuluan & & & \\
\hline & 1. Memotivasi siswa & 2 & 3 & 2,5 \\
\hline & 2. Menyampaikan tujuan pembelajaran & 2 & 2 & 2 \\
\hline & $\begin{array}{l}\text { Menghubungkan dengan pelajaran } \\
\text { 3. sebelumnya }\end{array}$ & 3 & 3 & 3 \\
\hline & $\begin{array}{l}\text { Mengatur siswa dalam kelompok- } \\
\text { 4. kelompok belajar }\end{array}$ & 3 & 2 & 2,5 \\
\hline & B. Kegiatan inti & & & \\
\hline & $\begin{array}{l}\text { Mempresentasikan langkah-langkah } \\
\text { 1. metode pembelajaran kooperatif }\end{array}$ & 3 & 4 & 3,5 \\
\hline & 2. Membimbing siswa melakukan kegiatan & 4 & 3 & 3,5 \\
\hline & 3. Melatih keterampilan kooperatif & 3 & 2 & 2,5 \\
\hline
\end{tabular}




\begin{tabular}{|c|c|c|c|c|}
\hline & $\begin{array}{l}\text { Mengawasi setiap kelompok secara } \\
\text { 4. bergiliran }\end{array}$ & 3 & 3 & 3 \\
\hline & $\begin{array}{l}\text { Memberikan bantuan kepada kelompok } \\
\text { 5. yang mengalami kesulitan }\end{array}$ & 3 & 3 & 3 \\
\hline & \multicolumn{4}{|l|}{ C. Penutup } \\
\hline & 1. Membimbing siswa membuat rangkuman & 3 & 4 & 3,5 \\
\hline & 2. Memberikan evaluasi & 3 & 2 & 2,5 \\
\hline II. & Pengelolaan Waktu & 2 & 3 & 2,5 \\
\hline \multirow{3}{*}{ III. } & Antusiasme Kelas & & & \\
\hline & 1. Siswa antusias & 3 & 4 & 3,5 \\
\hline & 2. Guru antusias & 2 & 3 & 2,5 \\
\hline \multicolumn{2}{|c|}{ Jumlah } & 39 & 41 & 40 \\
\hline & Keterangan: & Nilai & \multicolumn{2}{|c|}{ Kriteria } \\
\hline & & 1 & \multicolumn{2}{|c|}{ Tidak Baik } \\
\hline & & 2 & \multicolumn{2}{|c|}{ Kurang Baik } \\
\hline & & 3 & \multicolumn{2}{|c|}{ Cukup Baik } \\
\hline & & & \multicolumn{2}{|c|}{ Baik } \\
\hline
\end{tabular}

Dari tabel di atas, tanpak aspek-aspek yang diamati pada kegiatan belajar mengajar (siklus II) yang dilaksanakn oleh guru dengan menerapkan model pembelajarn kooperatif tipe STAD mendapatkan penilaian yang cukup baik dari pengamat. Maksudnya dari seluruh penilaian tidak terdapat nilai kurang. Namun demikian penilaian tesebut belum merupakan hasil yang optimal, untuk itu ada beberapa aspek yang perlu mendapatkan perhatian untuk penyempurnaan penerapan pembelajaran selanjutnya. Aspek-aspek tersebut adalah memotivasi siswa, membimbing siswa merumuskan kesimpulan/ menemukan konsep, dan pengelolaan waktu. Dengan penyempurnaan aspek-aspek I atas penerapan model pembelajarn kooperatif tipe STAD diharapkan siswa dapat menyimpulkan apa yang telah mereka pelajari dan mengemukakan pendapatnya sehingga mereka akan lebih memahami tentang apa ynag telah mereka lakukan. Berikut disajikan hasil observasi akivitas guru dan siswa : 
Tabel .5

Aktivitas Guru Dan Siswa Pada Siklus II

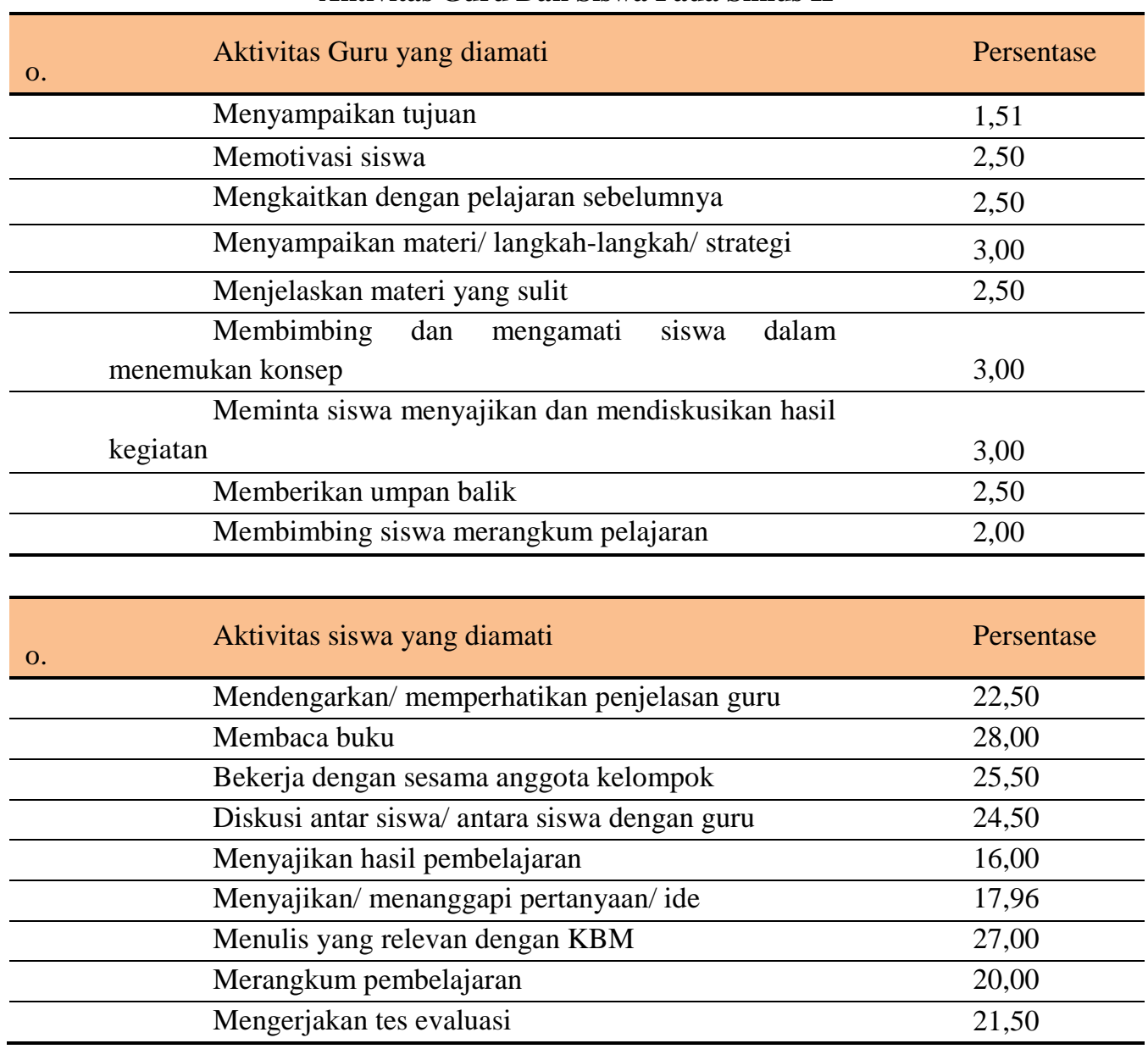

Berdasarkan tabel 5 di atas, tampak bahwa aktifitas guru yang paling dominan pada siklus II adalah membimbing dan mengamati siswa dalam menentukan konsep yaitu $3,00 \%$. Jika dibandingkan dengan siklus I, aktivitas ini mengalami peningkatan. Aktivitas guru yang mengalami penurunan adalah memberi umpan balik 2,50\%, menjelaskan materi yang sulit $2,50 \%$. Meminta siswa mendiskusikan dan menyajikan hasil kegiatan 3,00\%, dan membimbing siswa merangkum pelajaran 2,00\%.

Sedangkan untuk aktivitas siswa yang paling dominan pada siklus II adalah bekerja dengan sesama anggota kelompok yaitu 25,50\% jika dibandingkan dengan siklus I, aktifitas ini mengalami peningkatan. Aktifitas siswa yang mengalami penurunan adalah mendengarkan/memperhatikan penjelasan guru 22,50\%. Diskusi antar siswa/ antara siswa dengan guru $24,50 \%$, menulis yang relevan dengan KBM $27,00 \%$ dan merangkum pembelajaran 20,00\%. Adapun aktifitas siswa yang mengalami peningkatan adalah membaca buku 28,00\%, menyajikan hasil pembelajaran $16,00 \%$, menanggapi/mengajukan pertanyaan/ide $17,69 \%$. 
Tabel.6

Rekapitulasi Hasil Tes Formatif Pada Siklus II

\begin{tabular}{lll}
\hline No. & Uraian & Hasil Siklus II \\
\hline \hline 1. & Nilai rata-rata tes formatif & 74.47 \\
\hline 2. & Jumlah siswa yang tuntas belajar & 36 \\
\hline 3. & Persentase ketuntasan belajar & 87.80 \\
\hline
\end{tabular}

Berdasarkan tabel diatas diperoleh nilai rata-rata tes formatif sebesar 74.47 dan dari 41 siswa yang telah tuntas sebanyak 36 siswa dan 5 siswa belum mencapai ketuntasan belajar. Maka secara klasikal ketuntasan belajar yang telah tercapai sebesar $87.80 \%$ (termasuk kategori tuntas). Hasil pada siklus II ini mengalami peningkatan lebih baik dari siklus I. Adanya peningkatan hasil belajar pada siklus II ini dipengaruhi oleh adanya peningkatan kemampuan guru dalam menerapkan model pembelajaran kooperatif tipe STAD yang membuat siswa menjadi lebih terbiasa dengan pembelajaran seperti ini sehingga siswa lebih mudah dalam memahami materi yang telah diberikan.

Refleksi. Pada tahap ini akah dikaji apa yang telah terlaksana dengan baik maupun yang masih kurang baik dalam proses belajar mengajar dengan penerapan model pembelajaran kooperatif tipe STAD. Dari data-data yang telah diperoleh dapat diuraikan sebagai berikut: a) selama proses belajar mengajar guru telah melaksanakan semua pembelajaran dengan baik. Meskipun ada beberapa aspek yang belum sempurna, tetapi persentase pelaksanaannya untuk masing-masing aspek cukup besar, b) berdasarkan data hasil pengamatan diketahui bahwa siswa aktif selama proses belajar berlangsung, c) kekurangan pada siklus-siklus sebelumnya sudah mengalami perbaikan dan peningkatan sehingga menjadi lebih baik, d) hasil belajar siswsa pada siklus II mencapai ketuntasan.

Revisi Pelaksanaan. Pada siklus II guru telah menerapkan model pembelajaran kooperatif tipe STAD dengan baik dan dilihat dari aktivitas siswa serta hasil belajar siswa pelaksanaan proses belajar mengajar sudah berjalan dengan baik. Maka tidak diperlukan refisi terlalu banyak, tetapi yang perlu diperhatikan untuk tindakah selanjutnya adalah memaksimalkan dan mepertahankan apa yang telah ada dengan tujuan agar pada pelaksanaan proses belajar mengajar selanjutnya penerapan model pembelajaran kooperatif tipe STAD dapat meningkatkan proses belajar mengajar sehingga tujuan pembelajaran dapat tercapai. 


\section{PEMBAHASAN}

\section{Hasil belajar Siswa}

Ketuntasan Hasil belajar Siswa melalui hasil peneilitian ini menunjukkan bahwa model pembelajaran kooperatif tipe STAD memiliki dampak positif dalam meningkatkan Hasil Belajarbelajar siswa. Hal ini dapat dilihat dari semakin mantapnya pemahaman siswa terhadap materi yang disampaikan guru (ketuntasan belajar meningkat dari sklus I, dan II) yaitu masing-masing 58,54\% dan 87,80\%. Pada siklus II ketuntasan belajar siswa secara klasikal telah tercapai.

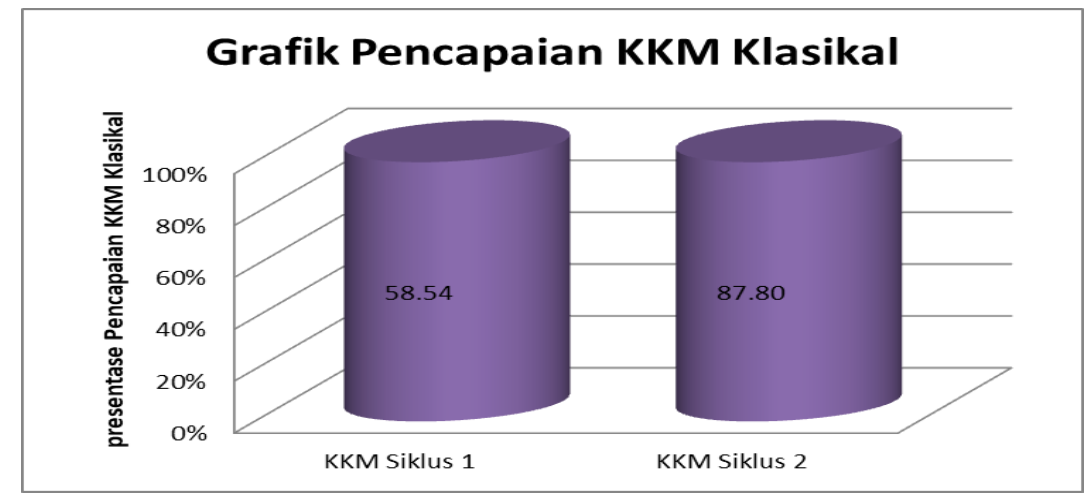

Grafik 1. Pencapaian KKM Klasikal

\section{Kemampuan Guru dalam Mengelola Pembelajaran}

Berdasarkan analisis data, diperoleh aktivitas siswa dalam setiap siklus mengalami peningkatan. Hal ini berdampak positif terhadap proses mengingat kembali materi pelajaran yang telah diterima selama ini, yaitu dapat ditunjukkan dengan meningkatnya nilai rata-rata siswa pada setiap siklus yang terus mengalami peningkatan.

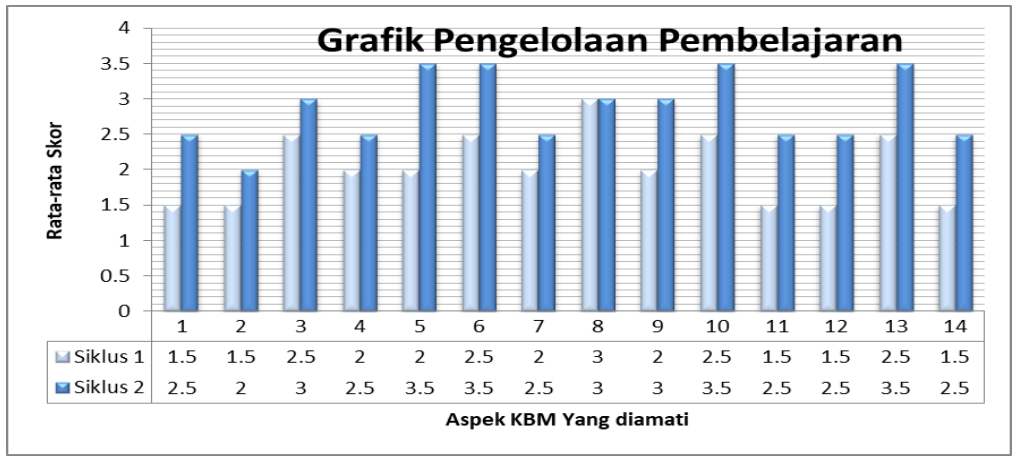

Grafik 2. Pengelolaan Pembelajaran

Keterangan:

Aspek KBM yang Diamati:

$1=\quad$ Memotivasi siswa 
$2=\quad$ Menyampaikan tujuan pembelajaran

3= Menghubungkan dengan pelajaran sebelumnya

$4=\quad$ Mengatur siswa dalam kelompok-kelompok belajar

$5=\quad$ Mempresentasikan langkah-langkah metode pembelajaran kooperatif

$6=\quad$ Membimbing siswa melakukan kegiatan

$7=\quad$ Melatih keterampilan kooperatif

$8=\quad$ Mengawasi setiap kelompok secara bergiliran

$9=\quad$ Memberikan bantuan kepada kelompok yang mengalami kesulitan

$10=$ Membimbing siswa membuat rangkuman

$11=\quad$ Memberikan evaluasi

$12=$ Pengelolaan Waktu

$13=$ Siswa antusias

$14=$ Guru antusias

\section{Aktivitas Guru dan Siswa Dalam Pembelajaran}

Untuk aktivitas guru selama pembelajaran telah melaksanakan langkahlangkah belajar aktif dengan baik. Hal ini terlihat dari aktivitas guru yang muncul di antaranya aktivitas membimbing dan mengamati siswa dalam mengerjakan kegiatan, menjelaskan, memberi umpan balik/evaluasi/tanya jawab dimana prosentase untuk aktivitas di atas cukup besar.

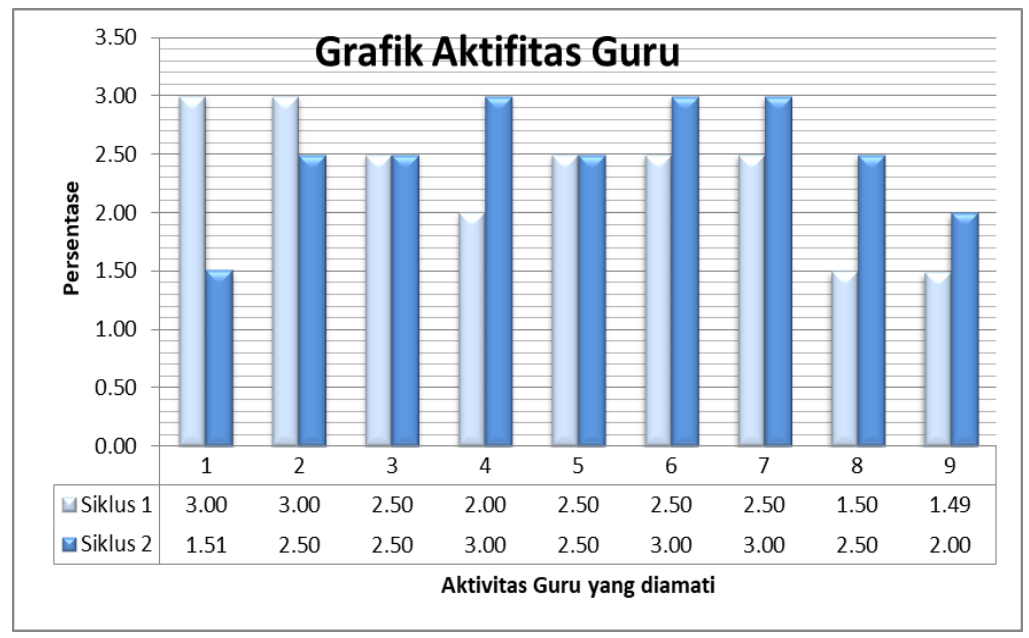

Grafik 3. Aktivitas Guru

Keterangan:

Aktivitas Guru yang diamati

$1=\quad$ Menyampaikan tujuan 
$2=\quad$ Memotivasi siswa

3= Mengkaitkan dengan pelajaran sebelumnya

$4=\quad$ Menyampaikan materi/ langkah-langkah/strategi

$5=\quad$ Menjelaskan materi yang sulit

$6=\quad$ Membimbing dan mengamati siswa dalam menemukan konsep

$7=\quad$ Meminta siswa menyajikan dan mendiskusikan hasil kegiatan

$8=\quad$ Memberikan umpan balik

$9=\quad$ Membimbing siswa merangkum pelajaran

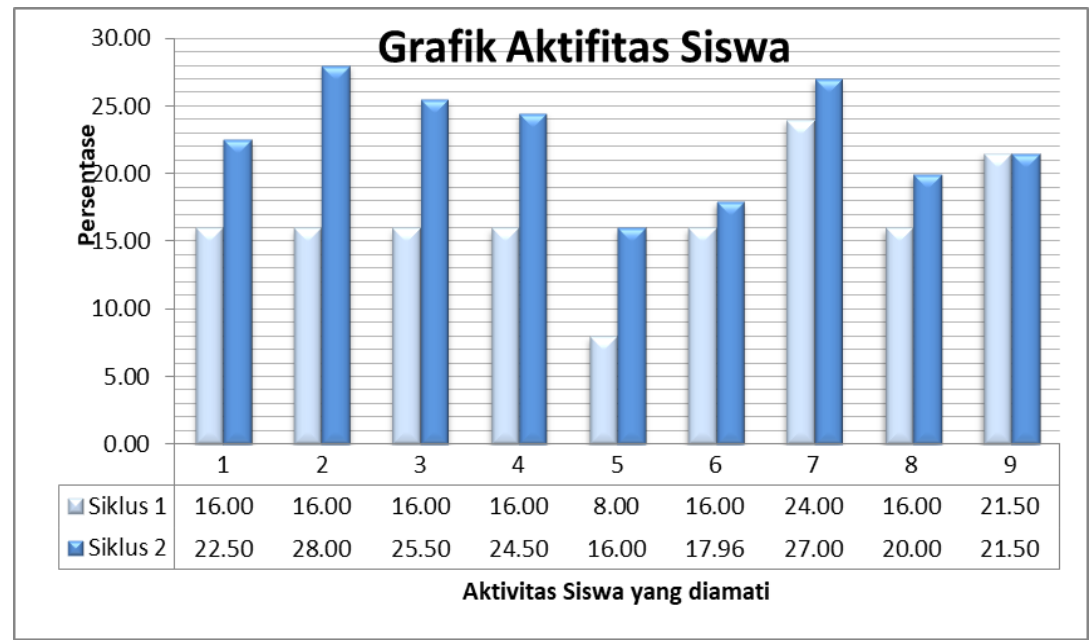

Grafik . Aktivitas Siswa

Keterangan:

Aktivitas Siswa yang diamati

$1=\quad$ Mendengarkan/ memperhatikan penjelasan guru

$2=\quad$ Membaca buku

$3=\quad$ Bekerja dengan sesama anggota kelompok

$4=\quad$ Diskusi antar siswa/ antara siswa dengan guru

$5=\quad$ Menyajikan hasil pembelajaran

$6=\quad$ Menyajikan/menanggapi pertanyaan/ide

$7=\quad$ Menulis yang relevan dengan KBM

$8=\quad$ Merangkum pembelajaran

$9=\quad$ Mengerjakan tes evaluasi

Berdasarkan analisis data, diperoleh aktivitas siswa yang paling dominan adalah membaca buku, mendengarkan penjelasan guru, dan diskusi antar siswa/antara 
siswa dengan guru. Jadi dapat dikatakan bahwa aktivitas siswa dapat dikategorikan aktif.

\section{SIMPULAN}

Pembelajaran kooperatif tipe STAD memiliki dampak positif dalam meningkatkan hasil belajar belajar siswa yang ditandai dengan peningkatan ketuntasan belajar siswa dalam setiap siklus, yaitu siklus I $(58,54 \%)$, dan siklus II $(87,80 \%)$. Kemudian hasil wawancara dengan beberapa siswa, rata-rata jawaban siswa menyatakan bahwa mereka tertarik dan berminat dengn model pembelajaran kooperatif tipe STAD sehingga mereka menjadi termotivasi untuk belajar.

\section{DAFTAR PUSTAKA}

Ali, M. (2013). Strategi Penelitian Pendidikan. Bandung : Angkasa. Anni, Catharina. Arikunto, S. (2002). Dasar-dasar Evaluasi Pendidikan. Jakarta: Rineka Cipta.

Slameto. (2010). Belajar dan Faktor-Faktor Yang Mempengaruhinya. Jakarta: Rineka Cipta

Siregar, E \& Hartini, N. (2010). Teori Belajar dan Pembelajaran. Bogor: Ghalia Indonesia.

Sudjana, N. (2005). Penilaian Hasil Proses Belajar Mengajar. Bandung: Remaja Rosdakarya.

Trianto. (2011). Mendesain Model Pembelajaran Inovatif-Progresif. Jakarta: Kencana 